\title{
SALIVA AND SALIVAOMICS IN THE DIAGNOSIS OF ORAL AND SYSTEMIC DISEASES: A REVIEW
}

KEY WORDS: Biosensors, Proteomics, Saliva, Salivaomics

\section{Dr.Sherly Ruth*}

Dr. Koduri Sridevi

Dr. Buduru

Krishnaveni

Dr. Nalli

Prasanth Kumar

Dr. Katru Sreekar

Post Graduate Student, Dept. of Oral Medicine and Radiology, Lenora Institute of Dental Sciences, Rajahmundry. *Corresponding Author

Professor and Head, Dept. of Oral Medicine and Radiology, Lenora Institute of Dental Sciences, Rajahmundry.

Reader, Dept. of Oral Medicine and Radiology, Lenora Institute of Dental Sciences, Rajahmundry.

Senior lecturer, Dept. of Oral Medicine and Radiology, Lenora Institute of Dental Sciences, Rajahmundry.

Post Graduate Student, Dept. of Oral Medicine and Radiology, Lenora Institute of Dental Sciences, Rajahmundry.

Dr. Komma Leela Ramani

Post Graduate Student, Dept. of Oral Medicine and Radiology, Lenora Institute of Dental Sciences, Rajahmundry.

The quest for novel strategies in early disease detection and response to therapy is an essential ongoing process in health care setups. Along with other body fluids such as blood, mucus, urine, semen and vaginal fluids; saliva can also be considered for the detection of the disease. The Salivary diagnostics is a dynamic field that is being incorporated as part of disease diagnosis, clinical monitoring and for making important clinical decisions for patient care. This review presents the translational value of saliva as a credible clinical diagnostic biofluid in detection, early detection of the various diseases and response to treatment.

\section{INTRODUCTION}

Mandel (1990) eloquently stated: "saliva is not one of the popular bodily fluids. It lacks the drama of blood, the sincerity of sweat and the emotional appeal of tears". However, this unpretentious secretion is a perfect medium that can be explored for health and disease surveillance.

The idea of using saliva in diagnostics was made in the second half of the 20th century with the two main objectives: early detection of certain diseases and monitoring the disease course in conjunction with treatment. A third objective can be implicated in the detection of addictive drugs or substances. ${ }^{[1]}$

\section{Physiology and composition of saliva.}

Saliva is a watery substance produced in the oral cavity of and constitutes about $98 \%$ of water, while the remaining $2 \%$ are electrolytes ( $\mathrm{Na}, \mathrm{K}, \mathrm{Ca}, \mathrm{Mg}$, hydrogen, carbonates), glycoprotein, antibacterial component such as certain types of immunoglobulins and lysozyme, and various enzymes like $\alpha$-amylase, lingual lipase.

However, the oral fluid is a complex mixture of primarily the secretory products from both major and minor salivary glands and also the secretions from the oropharynx, aerodigestive tracts and gingival sulcus admixed with food and blood derived compounds. ${ }^{[2]}$

The submandibular gland produces $70 \%$ of the overall volume, the parotid gland $25 \%$, and the sublingual gland about $5 \%$ with insignificant contribution from the minor salivary glands. Normal unstimulated whole saliva secretion ranges from $800-1500 \mathrm{ml} /$ day or 1.0 to $3.0 \mathrm{ml} /$ minute with a $\mathrm{pH}$ of $6-7 .^{[3]}$

Saliva plays a vital role in maintaining the oral health via lubrication, digestion, physical protection, cleansing, antibacterial action, gustation, buffering, maintenance of $\mathrm{pH}$ and tooth integrity (Table l).

Table 1: Functions and composition of saliva.

\begin{tabular}{|l|l|}
\hline Function & Components \\
\hline $\begin{array}{l}\text { Lubrication: Assists air flow, speech } \\
\text { and swallowing } \\
\text { Physical protection: Coats, protects } \\
\text { against mechanical, thermal, chemical } \\
\text { irritation. }\end{array}$ & $\begin{array}{l}\text { Mucin, } \\
\text { glycoproteins }\end{array}$ \\
\hline $\begin{array}{l}\text { Cleansing: Moistening assists } \\
\text { mastication, clearing food and } \\
\text { swallowing }\end{array}$ & \\
\hline $\begin{array}{l}\text { Ionic reserve: Modulates } \\
\text { demineralization and remineralization } \\
\text { of teeth }\end{array}$ & $\begin{array}{l}\text { Calcium phosphate, } \\
\text { statherins, proline- } \\
\text { rich proteins }\end{array}$ \\
\hline $\begin{array}{l}\text { Buffering: Modulates pH of biofilm } \\
\text { and buffering capacity of Saliva }\end{array}$ & $\begin{array}{l}\text { Bicarbonates, } \\
\text { phosphates, urea }\end{array}$ \\
\hline $\begin{array}{l}\text { Antibacterial action: Immunological } \\
\text { agents and non-immunological agents } \\
\text { help control oral microflora }\end{array}$ & $\begin{array}{l}\text { IgA, IgG, IgM } \\
\text { proteins, mucins, } \\
\text { peptides and } \\
\text { enzymes } \\
\text { (lactoferrin, } \\
\text { lysozyme, } \\
\text { peroxidase) }\end{array}$ \\
\hline $\begin{array}{l}\text { Pellicle formation: Proteins form a } \\
\text { protective layer on the teeth }\end{array}$ & $\begin{array}{l}\text { Macromolecular } \\
\text { proteins, stratherins, } \\
\text { histatins, cystatins, } \\
\text { proline-rich proteins }\end{array}$ \\
\hline $\begin{array}{l}\text { Digestion: Enzymes in saliva begin } \\
\text { the breakdown of starch and fat }\end{array}$ & $\begin{array}{l}\alpha \text {-amylase, lingual } \\
\text { lipase }\end{array}$ \\
\hline $\begin{array}{l}\text { Gustation: The solvent action and } \\
\text { hypotonicity of saliva enhance tasting } \\
\text { between nutrients and taste buds }\end{array}$ & \begin{tabular}{l} 
Protein, gustin, zinc \\
\hline
\end{tabular} \\
\hline
\end{tabular}

Why saliva can be used as a diagnostic fluid?

Saliva like serum also contains the biochemical substances such as hormones, enzymes, antibodies, growth factors and many of which enter the saliva from blood through passive diffusion, active transport and extracellular ultrafiltration. Further it has the ease of collection which is inexpensive and non-invasive and multiple samples can be obtained with minimal risk of cross-contamination. Manipulation required 
during diagnostic procedures is also would be less as compared to serum and it does not clot unlike blood. Saliva provides real-time diagnostic values and is more economical in terms of sampling, shipping and storage. ${ }^{[4]}$

\section{Collection of the Saliva}

Successful measurement of salivary parameters requires proper preparation of the subject and storage protocols as some of the important pre analytical steps. Various methods of collection of the saliva/ oral biofluid include:

- Draining, Spitting, Suction and Swab method for Whole saliva

- Suction and Cannulation method for Parotid saliva

- Suction, Cannulation and Segregator method for Submandibular/Sublingual secretion

Recent techniques of collection of saliva are mostly modifications of the expectoration methods of which Oragene, Saligene, Oracol and Verofy are a few ${ }^{[3]}$

\section{Salivaomics for different diseases:}

Identification and application of saliva-based "omics" biomarkers may overcome painful invasive procedures currently being used for the diagnosis of oral cancer. The term "Salivaomics" was coined in 2008, to indicate the research on the constituents of saliva which could be used as salivary biomarkers. ${ }^{[6]}$ (Table 2) Salivaomics includes five diagnostic alphabets: proteins, messenger RNAs, micro-RNAs (mi-RNAs), metabolic compounds, and microbes which offers substantial advantages for salivary diagnostics. ${ }^{[5}$

Table 2: Salivary Biomarkers and their applications.

\begin{tabular}{|l|l|}
\hline $\begin{array}{l}\text { Saliva/Oral biofluid } \\
\text { Biomarkers }\end{array}$ & Applications \\
\hline DNA & $\begin{array}{l}\text { In Standard genotyping, } \\
\text { Identifying Bacterial infection, } \\
\text { Diagnosing carcinomas of the } \\
\text { head and neck, In Forensics } \\
\text { for personnel identification }\end{array}$ \\
\hline RNA & $\begin{array}{l}\text { Viral/bacterial detection \& } \\
\text { identification \& hence } \\
\text { diagnosing the underlying } \\
\text { disease, Diagnosing } \\
\text { Carcinomas of the head and } \\
\text { neck }\end{array}$ \\
\hline Proteins & $\begin{array}{l}\text { In Diagnosing carcinomas of } \\
\text { the head and neck, diagnosing } \\
\text { periodontitis, Detecting dental } \\
\text { caries }\end{array}$ \\
\hline Mucins/glycoproteins & $\begin{array}{l}\text { In Diagnosing carcinomas of } \\
\text { the head and neck, Detecting } \\
\text { dental caries }\end{array}$ \\
\hline Immunoglobulins & $\begin{array}{l}\text { In Diagnosing viral infections } \\
\text { (HIV, hepatitis B and C) }\end{array}$ \\
\hline Metabolites & In Diagnosing periodontitis \\
\hline Drugs and their metabolites & $\begin{array}{l}\text { In Monitoring drug abuse, } \\
\text { Detection of drugs in the body }\end{array}$ \\
\hline &
\end{tabular}

\section{Genomics}

The saliva DNA yield (7.8 $\mathrm{g} / 0.5 \mathrm{~mL}$ saliva sample) using the manual purification method was comparable to the DNA yield from blood by the salt precipitation method $(7.4 \mathrm{ug} / 0.5 \mathrm{~mL}$ blood sample).$^{\left[{ }^{7]}\right.}$ Moreover, samples could be stored longterm without significant degradation. Salivary genetic and epigenetic analyses can provide gene-transcription profiles that could reflect abnormal pathological genetic processes.

\section{Transcriptomics}

The human salivary transcriptome consists mainly of mRNA and microRNA (miRNA). Other extracellular RNA molecules that function as salivary biomarkers include piwi interacting RNA (piRNA), circular RNA (circRNA), and small nucleolar RNA (snoRNA) ${ }^{\left[{ }^{8]}\right.}$ These salivary RNA biomarkers have been used to detect periodontal disease, Sjögren's syndrome, oral cancer, lung cancer, breast cancer, ovarian cancer, and pancreatic cancer.

Salivary mRNAs, as well as endogenous miRNAs, are protected from ribonucleases by exosomes in the saliva and are therefore quite resistant to degradation. However, research into salivary miRNAs has become an emerging field because these miRNAs are more stable than mRNAs, and it is relatively easy to distinguish the miRNA expression levels between healthy and abnormal cells. The five most abundant salivary miRNAs are miR223, miR-191, miR-16, miR-203, and miR-24. ${ }^{\left[{ }^{[9}\right.}$

\section{Proteomics}

More than 3000 proteins have been detected in human saliva, and many have been used as biomarkers for disease detection. Elashoff et al. identified several proteomic biomarkers for oral cancer detection, including IL-1 beta and IL-8. ${ }^{[10]}$ Rai et al. showed that adenosine deaminase might be used as a diagnostic tool for early detection of squamous cell carcinoma of the tongue. ${ }^{[11]}$ Sweet et al., demonstrated calprotectin might aid in the diagnosis of oral candidiasis. ${ }^{[12]}$ In 2004, a multi-institutional, multidisciplinary research consortium was initiated and funded by the National Institute of Dental and Craniofacial Research (NIDCR) to generate a complete catalog of all salivary secretory proteins (Human Salivary Proteome Project). This collaborative endeavor yielded 1,166 identifications in ductal fluid: 914 in parotid and 917 in submandibular/sublingual saliva. ${ }^{[13]}$ The typical protein concentration of saliva is $0.7-2.4 \mathrm{mg} / \mathrm{mL}{ }^{[14]}$

\section{Metabolomics}

Cells produce a multitude of metabolites as the final products of cellular biochemical processes like gene transcription, mRNA translation, protein synthesis, and metabolic enzymatic reactions. The comprehensive identification, quantification, and analysis of these metabolites are known as "metabolomics." Techniques such as the combination of capillary electrophoresis (CE) and a time-off light mass spectrometer (TOFMS), allow the detection of various metabolites and only require a small sample. Studies of the oral metabolome using CE-TOFMS may provide researchers and clinicians with insights regarding the diagnosis of oral diseases in specific sites as well as the clinical effects of various therapeutics in the oral cavity. ${ }^{[15]}$

\section{Exosomics}

Exosomes are 30-100nm cell derived vesicles released by most cells in the body upon the fusion of multivesicular bodies (MVBs) with the plasma membrane. These vesicles have essential biological functions, including intercellular signaling and macromolecular trafficking. The content of these microvesicles includes RNAs, lipids, proteins, immunoglobulins, enzymes. Recent studies suggest that salivary exosomes play important role in oral cancers and have the potential of becoming biomarkers. ${ }^{[16]}$ This may obviate the limitations of the whole saliva, including sample contamination and the presence of proteins such as amylase that can mask other proteins with low expression.

\section{Salivary biomarkers for Specific Diseases}

\section{Table 3: Salivary biomarkers for various diseases}

\begin{tabular}{|c|c|}
\hline Diseases & Salivary markers \\
\hline $\begin{array}{l}\text { Dental Caries and } \\
\text { Demineralization } \\
\text { Diseases }\end{array}$ & $\begin{array}{l}\downarrow \text { salivary flow rate } \downarrow \text { buffering } \\
\text { capacity } \downarrow \text { sugar clearance rate } \downarrow \text { pH. }\end{array}$ \\
\hline $\begin{array}{l}\text { Periodontal } \\
\text { Diseases and Peri- } \\
\text { Implantitis }\end{array}$ & $\begin{array}{l}\uparrow \text { Matrix metalloproteinase-8 (MMP-8), } \\
\uparrow \text { Interleukin-1 beta (IL-1 beta), and } \\
\text { interleukin-6 (IL-6), } \\
\uparrow \text { Macrophage-activating factor (MAF), } \\
\uparrow \text { Macrophage inflammatory protein } 1 \\
\text { alpha (MIP-1 alpha), } \\
\uparrow \text { Myeloperoxidase (MPO) and } \\
\text { lactoferrin, } \\
\uparrow \text { C-reactive proteins (CRP), } \\
\uparrow \text { RANKL/ OPG ratio }\end{array}$ \\
\hline
\end{tabular}




\begin{tabular}{|c|c|}
\hline $\begin{array}{l}\text { Myocardial } \\
\text { infarction }\end{array}$ & $\begin{array}{l}\uparrow \text { Cardiac troponins I (TnI) and T (TnT), } \\
\uparrow \text { Creatine kinase-MB, } \\
\uparrow \text { C-reactive proteins (CRP), } \\
\uparrow \text { TNF- } \alpha, \\
\uparrow \text { MMP-9 and } \\
\uparrow \text { Myeloperoxidase } \\
\uparrow \text { Myoglobin }\end{array}$ \\
\hline Oral Cancers & $\begin{array}{l}\text { Oncogenes (C-myc, C-Fos, C-Jun), } \\
\text { Cytokines (TGF-Beta, IL-8, IL-1 Beta), } \\
\text { Extracellular Matrix Degrading } \\
\text { Protease (MMP-1, MMP-2, MMP-3, MMP- } \\
\text { 9), Hypoxia Markers (HIF - Alpha, CA - } \\
\text { 9), Epithelial Tumour Factors CYFRA } \\
\text { 2l-l(a fragment of cytokeratin 19), } \\
\text { Cytokeratin (CK 13, 14, 16), Micro RNA } \\
\text { Molecules, Hypomethylation of cancer- } \\
\text { related genes (p16, DAP - K), salivary } \\
\text { defensin-1, etc. have been found to } \\
\text { contain individual histone and miRNA } \\
\text { alterations that are HNC specific } \\
\downarrow \text { miR - 125a, miR - 200 (down regulation) }\end{array}$ \\
\hline $\begin{array}{l}\text { Risk of oral } \\
\text { mucositis in HNC } \\
\text { patients }\end{array}$ & $\begin{array}{l}\uparrow \text { EGF (epidermal growth factor), } \\
\uparrow \text { CRP (C-reactive protein), } \\
\uparrow \text { TNF-alpha (tumor necrosis factor } \\
\text { alpha), and } \\
\uparrow \text { ESR (erythrocyte sedimentation rate) }\end{array}$ \\
\hline Breast cancer & Overexpression of Glycoprotein CA 15-3 \\
\hline Lung cancer & $\begin{array}{l}\text { Overexpression of HP, AZGPl, human } \\
\text { calprotectin }\end{array}$ \\
\hline Gastric cancer & $\begin{array}{l}\text { Expression of Proteins } 6556.81 \mathrm{Da} \text { and } \\
7081.17 \mathrm{Da}\end{array}$ \\
\hline $\begin{array}{l}\text { Oral Lichen } \\
\text { Planus }\end{array}$ & $\begin{array}{l}\downarrow \text { Cystatin SA } \\
\uparrow \text { Chain C of the complement system } \\
\text { and Chain B found in D -a fragment of } \\
\text { fibrinogen }\end{array}$ \\
\hline $\begin{array}{l}\text { Sjögren's } \\
\text { Syndrome }\end{array}$ & $\begin{array}{l}\uparrow \text { Actin, alpha-actin-l, Ig gamma-l chain } \\
\text { C region, B2-microglobulin, Ig receptor } \\
\text { polymeric salivary amylase, lysozyme } \\
\text { C, carbonic anhydrase VI, cystatin C, } \\
\text { polymeric } \\
\uparrow \text { Ig receptor, prolactin-inducible } \\
\text { protein, cystatin SN, calgranulin A and B, } \\
\text { fatty acids protein binding, anti- } \\
\text { transglutaminase, anti-histone, anti-SSA } \\
\text { and anti-SSB. } \\
\text { Sodium, chloride, IgA, IgG, lactoferrin, } \\
\text { albumin, soluble IL-2 receptor }\end{array}$ \\
\hline C liac disease & $\begin{array}{l}\text { Tissue anti-transglutaminase (TTG) } \\
\text { antibodies }\end{array}$ \\
\hline Cystic fibrosis & $\begin{array}{l}\uparrow \text { Prostaglandin E2, } \\
\uparrow \text { Lipids, Electrolytes, Urea, Uric acid, } \\
\text { Total protein (from the Submandibular } \\
\text { salivary gland). } \\
\text { Unusual form of EGF } \\
\uparrow \text { Calcium and Phosphate levels (In } \\
\text { children) }\end{array}$ \\
\hline $\begin{array}{l}\text { Bone turn over } \\
\text { markers }\end{array}$ & 个 Salivary osteonectin, ALP activity \\
\hline Forensic evidence & Blood group antigens, DNA testing \\
\hline $\begin{array}{l}\text { Cushing's } \\
\text { Syndrome }\end{array}$ & Cortisol is elevated \\
\hline Diabetes mellitus & $\begin{array}{l}\uparrow \text { Melatonin, } \\
\uparrow \text { Oxidized glutathione, Cysteine } \\
\text { glutathione disulphide, } \\
\uparrow \text { Amino acids, } \omega-3 \text { fatty acid } \\
\text { (docosapentaenoate) and } \omega-6 \text { fatty acids } \\
\text { (linoleate and arachidonate), } \\
\uparrow \text { Glucose, } \\
\uparrow \alpha \text {-hydroxybutyrate }\end{array}$ \\
\hline Stress & $\uparrow$ Salivary $\alpha$-amylase \\
\hline
\end{tabular}

The clinical use of saliva testing occurred as early as 1836 in patients with bronchitis. ${ }^{[17]}$ More recent studies have focused on detection of steroid hormones and antibodies in the saliva. Determining hormone levels, including estradiol (indicator of premature birth and low birth weight babies), progesterone and testosterone,DHEA in saliva is possible. ${ }^{[13]}$ (Table 4)

Table 4: Detection of various drugs and medications in saliva

\begin{tabular}{|l|l|}
\hline Substances & Characteristics of salivary detection \\
\hline Drugs & $\begin{array}{l}\text { Salivary concentration of ethanol is 9\% } \\
\text { greater than in plasma. }\end{array}$ \\
\hline Alcohol & $\begin{array}{l}\text { Presence of metabolites: cotinine and 3- } \\
\text { hydroxycotinine. }\end{array}$ \\
\hline Nicotine & $\begin{array}{l}\text { Salivary THC(Delta-9- } \\
\text { tetrahydrocannabinol) is detectable } \\
\text { very early and remains for up to 14h. }\end{array}$ \\
\hline Cannabis & $\begin{array}{l}\text { Salivary levels remain high up to lhour } \\
\text { after administering the drug. (Similar to } \\
\text { blood levels). }\end{array}$ \\
\hline Amphetamine & $\begin{array}{l}\text { Detectable 10 minutes after } \\
\text { administration for up to 72hours. }\end{array}$ \\
\hline Methamphetamine & $\begin{array}{l}\text { Detectable up to 8.1-1 l.1 hours after } \\
\text { being inhaled, smoked and ingested. }\end{array}$ \\
\hline Heroine & $\begin{array}{l}\text { Salivary levels reach max concentration } \\
\text { after } 2 \text { minutes (similar to blood levels). }\end{array}$ \\
\hline Medication & $\begin{array}{l}\text { Highest salivary concentration lh after } \\
\text { administration and remains stable for } \\
\text { 50 hours. }\end{array}$ \\
\hline Barbiturates & $\begin{array}{l}\text { Nordiazepam, oxazepam, appears in } \\
\text { saliva 45 minutes after administration. }\end{array}$ \\
\hline Benzodiazepines & $\begin{array}{l}\text { Detected in saliva 1 hour after being } \\
\text { taken (concentration in saliva 3-4 times } \\
\text { greater than in plasma) }\end{array}$ \\
\hline Codeine & $\begin{array}{l}\text { Detected in saliva soon after parenteral } \\
\text { administration. }\end{array}$ \\
\hline
\end{tabular}

\section{Saliva based biosensors}

Biosensors are small, self-contained analytical devices used for the detection and measurement of a particular substance (analyte) of interest ${ }^{[18]}$ Wide range of diseases can be diagnosed with different biomarkers and biosensors. (Table 5)

Table 5: Salivary biosensors for various diseases

\begin{tabular}{|l|l|l|}
\hline Disease & Target/biomarker & Biosensor \\
\hline Caries $^{[19,20]}$ & $\begin{array}{l}\text { Streptococcus } \\
\text { mutans } \\
\text { Saa }\end{array}$ & $\begin{array}{l}\text { Fiber-optic biosensor } \\
\text { sAA biosensor }\end{array}$ \\
\hline Periodontitis ${ }^{[2]]}$ & $\begin{array}{l}\text { IL-1 } \beta \\
\text { MMP-8 }\end{array}$ & $\begin{array}{l}\text { Lab-on-a-chip } \\
\text { multiplex biosensor }\end{array}$ \\
\hline $\begin{array}{l}\text { Oral cancer } \\
{[22,23,24]}\end{array}$ & $\begin{array}{l}\text { IL-8 } \\
\text { EGFR } \\
\text { mi-RNA }\end{array}$ & $\begin{array}{l}\text { Optical protein sensor } \\
\text { Nano-biochip cellular } \\
\text { analysis sensor } \\
\text { Electrochemical } \\
\text { biosensor }\end{array}$ \\
\hline $\begin{array}{l}\text { Diabetes } \\
\text { mellitus }{ }^{[25]}\end{array}$ & Glucose & $\begin{array}{l}\text { Salivary nano } \\
\text { biosensor }\end{array}$ \\
\hline HIV ${ }^{[26]}$ & $\begin{array}{l}\text { Immunoglobulin } \\
\text { peptide-based } \\
\text { sensors }\end{array}$ \\
\hline $\begin{array}{l}\text { Stress induced } \\
\text { disorders }\end{array}{ }^{[27]}$ & Cortisol & $\begin{array}{l}\text { Flow filtered ported } \\
\text { SPR biosensor }\end{array}$ \\
\hline $\begin{array}{l}\text { Cardiovascular } \\
\text { disease }{ }^{[28,29]}\end{array}$ & $\begin{array}{l}\text { CRP } \\
\text { Lactate }\end{array}$ & $\begin{array}{l}\text { Microchip assay } \\
\text { biosensor } \\
\text { Electrochemiluminesc } \\
\text { ence biosensor }\end{array}$ \\
\hline $\begin{array}{l}\text { Hyperphosphat } \\
\text { emia in chronic } \\
\text { renal failure }\end{array}$ & Phosphate & $\begin{array}{l}\text { Amperometric } \\
\text { biosensor }\end{array}$ \\
\hline
\end{tabular}




\begin{tabular}{|l|l|l|}
\hline Obesity $^{[30,31]}$ & $\begin{array}{l}\text { Phosphate } \\
\text { Uric acid }\end{array}$ & $\begin{array}{l}\text { Amperometric } \\
\text { biosensor } \\
\text { Mouth guard } \\
\text { biosensor }\end{array}$ \\
\hline $\begin{array}{l}\text { Breast cancer } \\
{[32,33,34]}\end{array}$ & $\begin{array}{l}\text { ATP6AP1 } \\
\text { CA15-3, CEA } \\
\text { CA125 } \\
\text { HER-2/neu(c-erbB- } \\
\text { 2) }\end{array}$ & $\begin{array}{l}\text { Quartz crystal } \\
\text { biosensor } \\
\text { Surface plasma } \\
\text { resonance biosensor } \\
\text { Multiplexed } \\
\text { microfluidic biosensor }\end{array}$ \\
\hline
\end{tabular}

\section{Limitations for the use of saliva as diagnostic fluid ${ }^{[4]}$}

Salivary composition can be influenced by the method of collection and the extent of stimulation of salivary flow. Changes in salivary flow rate (shows inter and intra individual variability) may affect the concentration of salivary markers and also their availability due to changes in salivary $\mathrm{pH}$.

Levels of certain markers in saliva are not always a reliable reflection of the levels of these markers in serum. Some systemic disorders, medications and radiation may affect salivary gland function and consequently the quantity and composition of saliva. Also, many serum markers may reach whole saliva in an unpredictable way (i.e., gingival crevicular fluid flow and through oral wounds) and proteolytic enzymes derived from the host and oral microorganisms. These parameters will affect the diagnostic usefulness of many salivary constituents.

\section{CONCLUSION}

A drop of saliva harbors a world of diagnostic information, proteomically and genomically. Saliva is an epitome of a noninvasive, readily-available, easy to collect, transport, and store "biofluid." Since the emphasis is switching more towards high impact personalized medicine, pioneering "Point-of-care salivary technologies" are being developed. Although blood is the gold standard for the diagnosis of drugs and diseases, the success of saliva as a diagnostic media is guaranteed, particularly for substances that reflect or can be directly correlated with systemic analytes. It is almost certain, that in the forthcoming years, home testing kits incorporating oral fluid biosensors may begin to appear, outperforming the routine laboratory tests in the diagnosis of diseases.

\section{REFERENCES}

1. Pandey V, Upadhayaya V, Tripathi J, Pandey S, Sidhu GK. Saliva- A Diagnostic Fluid:A Review. Int JDent Med Res 2014;1 (3):149-54

2. Israa Mohammed Dawood, Sulafa K. El-Samarrai. Saliva and Oral Health. Int.J. Adv. Res. Biol. Sci. 2018;5(7):1-45.

3. Yamuna Priya K, Muthu Prathibha K. Methods of collection of saliva - A Review. International Journal of Oral Health Dentistry 2017;3(3): 149-53.

4. Shah S. Salivaomics: the current scenario. J Oral Maxillofac Pathol 2018; 22: 375-81.

5. Poornima G, Mahesh Kumar TS. Genomic Alphabets of Saliva as a Biomarker in Oral Cancer.J Indian Acad Oral Med Radiol 2017;29:300-5.

6. Kaczor-Urbanowicz KE, Martin Carreras-Presas C, Aro K, Tu M, Garcia-Godoy F,Wong DTW.Saliva diagnostics - Current views and directions. Exp Biol Med. 2017;242(5):459-72.

7. Looi, M.-L., Zakaria, H., Osman, J. \& Jamal, R. Quantity and quality assessment of DNA extracted from saliva and blood. Clin. Lab.2012;58(3-4):307-12.

8. Wong, D. T. W. Salivary Extracellular Noncoding RNA: Emerging Biomarkers for Molecular Diagnostics. Clinical Therapeutics 2015;37(3):540-51.

9. Kulkarni, V., Uttamani, J. R., Naqvi, A. R., \& Nares, S. microRNAs: Emerging players in oral cancers and inflammatory disorders. Tumor Biology 2017;39(5):1-12

10. Nguyen TTH, Sodnom-Ish B, Choi SW, et al. Salivary biomarkers in oral squamous cell carcinoma. J Korean Assoc Oral Maxillofac Surg. 2020;46(5):301-12

11. Rai, B., Kaur, J., Jacobs, R., \& Anand, S. C. Adenosine deaminase in saliva as a diagnostic marker of squamous cell carcinoma of tongue. Clinical Oral Investigations 2010;15(3):347-9.

12. Sweet, S.P.,Denbury, A.N., \& Challacombe, S.J.Salivary calprotectin levels are raised in patients with oral candidiasis or Sjogren's syndrome but decreased by HIV infection. Oral Microbiology and Immunology 2001;16(2):119-23.

13. Bradley Stephen Henson and David T. Wong.Collection, Storage, and Processing of Saliva Samples for Downstream Molecular Applications Oral Biology. Methods in Molecular Biology 2010;666:21-30.

14. Katsani and Sakellari J of Biol Res-Thessaloniki 2019;26:17

15. DeLaney K, Sauer CS, Vu NQ, Li L. Recent Advances and New Perspectives in Capillary Electrophoresis-Mass Spectrometry for Single Cell "Omics". Molecules.2018;24(1):42.

16. Cheng J, Nonaka T, Wong DTW. Salivary Exosomes as Nanocarriers for Cancer Biomarker Delivery. Materials (Basel). 2019;12(4):654.

17. Johnson, M.D., James; Johnson, Esq., Henry James, eds. "The Medicochirurgical Review and Journal of Practical Medicine"1836;231-3

18. Malon, R. S. P., Sadir, S., Balakrishnan, M., \& Córcoles, E. P. Saliva-Based Biosensors: Noninvasive Monitoring Tool for Clinical Diagnostics. BioMed Research International, 2014;1-20.

19. Kishen A, John MS, Lim CS, Asundi A. A fiber optic biosensor (FOBS) to monitor mutans streptococci in human saliva. Biosens Bioelectron 2003;18:13718.

20. Shetty V, Zigler C, Robles TF, Elashoff D, Yamaguchi M. Developmental validation of a point of care, salivary $\alpha$ amylase biosensor. Psychoneuroendocrinology 2011;36:1939.

21. Ji S, Choi Y. Point of care diagnosis of periodontitis using saliva: Technically feasible but still a challenge. Front Cell Infect Microbiol 2015;5:65.

22. Tan W, Sabet L, Li Y, Yu T, Klokkevold PR, Wong DT, et al. Optical protein sensor for detecting cancer markers in saliva. Biosens Bioelectron 2008;24:266 71.

23. Weigum SE, Floriano PN, Redding SW, Yeh CK, Westbrook SD, McGuff HS, et al. 
Nano bio chip sensor platform for examination of oral exfoliative cytology. Cancer Prev Res (Phila) 2010;3:51828.

24. Wang $\mathrm{Z}$, Zhang J, GuoY,Wu X,Yang W, Xu L, et al. A novel electrically magnetic controllable electrochemical biosensor for the ultrasensitive and specific detection of attomolar level oral cancer related microRNA. Biosens Bioelectron 2013;45:108 13.

25. Zhang W, Du Y, Wang ML. Noninvasive glucose monitoring using saliva nanobiosensor. Sens Biosensing Res 2015;4:239.

26. McQuistan A, Zaitouna AJ, Echeverria E, Lai RY. Use of thiolated oligonucleotides as anti fouling diluents in electrochemical peptide based sensors. Chem Commun (Camb) 2014;50:46902.

27. Stevens RC, Soelberg SD, Near S, Furlong CE. Detection of cortisol in saliva with a flow filtered, portable surface plasmon resonance biosensor system. Anal Chem 2008;80:6747 51.

28. Christodoulides N, Mohanty S, Miller CS, Langub MC, Floriano PN, Dharshan $\mathrm{P}$, et al. Application of microchip assay system for the measurement of $\mathrm{C}$ reactive protein in human saliva. Lab Chip 2005;5:261 9.

29. Ballesta Claver J, Valencia Mirón MC, Capitán Vallvey LF. Disposable electrochemiluminescent biosensor for lactate determination in saliva. Analyst 2009; 134:1423 32 .

30. Kwan RC, Leung HF, Hon PY, Cheung HC, Hirota K, Renneberg R. Amperometric biosensor for determining human salivary phosphate. Anal Biochem 2005;343:263 7.

31. Kim J, Imani S, de Araujo WR, Warchall J, Valdés Ramírez G, Paixão TR, et al. Wearable salivary uric acid mouthguard biosensor with integrated wireless electronics. Biosens Bioelectron 2015;74:1061 8

32. Arif S, Oudsia S, Urooj S, Chaudry N, Arshad A, Andleeb S. Blueprint of quartz crystal microbalance biosensor for early detection of breast cancer through salivary autoantibodies against ATP6AP1. Biosens Bioelectron 2015;65:62 70.

33. Liang YH, Chang CC, Chen CC, Chu SuY, Lin CW. Development of an Au/ZnO thin film surface plasmon resonance based biosensor immunoassay for the detection of carbohydrate antigen 153 in human saliva. Clin Biochem 2012;45:1689 93.

34. Jokerst JV, Raamanathan A, Christodoulides N, Floriano PN, Pollard AA Simmons GW, et al. Nano bio chips for high performance multiplexed protein detection: determinations of cancer biomarkers in serum and saliva using quantum dot bioconjugate labels. Biosens Bioelectron 2009;24:3622 9.

35. Herr AE, Hatch AV, Giannobile WV, Throckmorton DJ, Tran HM, Brennan JS, et al. Integrated microfluidic platform for oral diagnostics. Ann N Y Acad Sci 2007;1098:362 74 .

36. William V. Giannobile Salivary diagnostics for periodontal diseases. JADA 2012;143(10 suppl).

37. Floriano PN, Christodoulides N, Miller CS, et al. Use of saliva-based nanobiochip tests for acute myocardial infarction at the point of care: a feasibility study. Clin Chem. 2009;55(8):1530-38.

38. Islam, K. U., \& Iqbal, J. An Update on Molecular Diagnostics for COVID-19. Frontiers in Cellular and Infection Microbiology 2020;10.

39. Dr. David Wong Salivary diagnostics: Enhancing disease detection and making medicine better. European Journal of Dental Education 2008;12 Suppl 1:22-9. 